\title{
Identita - Autenticita - Diference - Distance: základní problémy kulturní a národní sebeidentifikace
}

\author{
Břetislav Horyna \\ Univerzita Konštantína Filozofa Nitra, SK
}

HORYNA, B.: Identity - Authenticity - Difference - Distance. The Basic Problems of Cultural and National Self-identification

Philosophica Critica, vol. 6, 2020, no. 2, ISSN 1339-8970, pp. 56-71.

The purpose of this study is regulative: a consideration of the possibilities of using the term identity appropriately to its meaning. At the same time, I understand identity as a regulative principle, which provides direction to identity as a mode of social experience, but in no way ensures its contents. Specifically, I will articulate my thoughts on the relation between difference (the distinctions and possibilities of identity as a differentiating factor) and distance (detachment, spacing and possibilities of identity as a collective actio per distans). I will pose and attempt to answer the question of whether the term identity can be infused through sources, which each self-identifying subject (the individual, various communicative public groupings, nations, cultures, civilisations) creates through active, energetic action.

Keywords: Identity - Crisis of identity - Self-identity - Autenticity Difference - Distance - Nationalism - Mental maturity

\section{Úvod}

V článku pro časopis Philosophica Critica (Horyna 2019), kde jsem se věnoval několika otázkám identity, jsem popřel, že by identita mohla náležet mezi clare et distincte vymezitelné pojmy, které vyžaduje přísná věda, že by mohla tvořit autonomní hodnotu a napsal jsem, že „,je myslitelná jako modus sociální zkušenosti“, jakých je ovšem mnoho. $\mathrm{V}$ tomto volně navazujícím textu se pokusím popsat několik dalších souvislostí, v kterých identita jako korelativní termín stojí, a z nich odvodit jeho možný význam. Účel, který zde sleduji, je tudíž regulativní, tzn. jedná se o upravení možností používání termínu identita adekvátně jeho významu; při tom budu 
chápat identitu jako regulativní princip, jenž dává identitě pochopené jako modus sociální zkušenosti směr, ale $\mathrm{v}$ žádném případě nezabezpečí její obsah. Vyjádřím se speciálně k relaci mezi diferencí (rozdílem a možností identity jako diferenciačního faktoru) a distancí (odstupem, rozestupem a možností identity jako skupinové actio per distans). Zazní také otázka, zda lze termín identity naplnit prostřednictvím zdrojů, které každý sebeidentifikující se subjekt (individuum, různé komunikativní veřejnosti národ, kultura, civilizace) musí vytvářet svým aktivním činným jednáním. Její řešení nabízí východisko z mrtvé esencialistické představy, která se zakládá na nedoložitelném předpokladu existence jakéhosi společného civilizačního „fundusu“, v kterém jsou uloženy společné či dokonce univerzální hodnoty a čekají na své upotřebení v zájmu sebepotvrzení daného subjektu. Stavím se tím proti iluzi národů, kultur a civilizací jako střádalů hodnot, penzí a mravních obročí, která zastavuje jakýkoli kulturní pohyb a změnu, a kladu důraz na tvorbu individuálního a společenského bohatství (na „úrodu“, kterou lze položit na diskusní stůl a srovnat ji s „úrodou“ jiných subjektů, a teprve z této komparace odvozovat, kdo je kdo, ke komu a čemu patř́i a čím se může oprávněně pyšnit).

\section{Jak identifikovat identitu}

Jak může individuum oznámit vlastní identitu? Znamená znát vlastní identitu to, že člověk zná své jméno a osobní data, která mu přidělil někdo jiný (stát přiděluje údaje, rodné číslo, aby mohl provádět „kontrolu identity“)? V tomto smyslu neoznačuje identita žádnou kvalitu, v zásadě jen pořadí, v kterém jsme přišli na svět, a znak, který nám přidělil státní útvar, v němž se tak stalo.

Mezi identitou ve smyslu identičnosti jako faktu ztotožnění a identitou ve smyslu kvality, s níž se identifikujeme (jsme identifikováni), musí vždy spočívat tento spojující článek pocházející z byrokratické správy společenství (občanského práva, administrativy, policejní kontroly) - když nebudu uznán jako identická osoba, ztratím možnost sebeidentifikace a identifikace s něčím dalším. Avšak to, že jsem dostal např jméno „Břetislav“, nezakládá mou identifikaci $s$ dalšími osobami téhož jména: skupinová identita založená na administrativně přidělených znacích neexistuje. Přidělení jména je naopak rozhodující pro sebeidentifikaci uvnitř společenství ostatních jmen - vím, že jsem „Břetislav“, nikoli „Klement“, což zakládá identifikační rozdíl. Je tudíž identifikační kvalitou právě diference? Pak bych mohl použít další podobně diferenciační znaky, které by vedly k sebeidentifikaci: jsem občan státu, který se sám politicky identifikuje s demokratickou státností - tzn. že mám občanství demokratického státu 
jménem Česká republika. Tento stát ale vznikl 1. ledna 1993: předtím jsem byl (po descendenční ose) občan České a Slovenské federativní republiky, Československé federativní republiky, Československé socialistické republiky a Československé republiky: mohu se identifikovat se všemi těmito historicky již neexistujícími útvary proto, že se nepochybně podílely na formování mého myšlení, nebo se mám identifikovat pouze s dnes existujícím státem (o jehož základním sebeidentifikačním politickém znaku, demokracii, mám navíc vážné pochybnosti)? Narození v určitém státě je plně kontingentní, ale interpretuje se jako zásadní věcný faktor možnosti naší identity: důvody jsou víceméně zřejmé, důsledkům však taková zřetelnost chybí: žil jsem v pěti státech, které nelze chápat jako stále týž, tzn. identifikuji se zemí svého narození, jež mění své vlastní identifikační znaky včetně jména jak na běžícím pásu? Zůstalo snad za oněmi změnami něco esenciálního, neměnného? Sotva, protože se zásadně změnily hranice, obyvatelstvo a státní jazyk; kdybych si, zcela hypoteticky, s každou změnou jména své rodné země změnil také svoje jméno, jaká by byla moje identita?

Sdělení, že nějaká věc je identická sama se sebou, je - řečeno Wittgensteinovými slovy - nejkrásnější př́íklad úplně zbytečné věty: její „pravdivostní hodnotu“ verifikujeme tak, že představu určité věci, kterou máme, vložíme do představy její formy a zjistíme, že „pasuje“. ${ }^{1}$ Samozřejmě že věc je sebeidentická, protože je stejná: jde o stejnost, „nepochybné paradigma“ určení věci; mám-li před sebou věc, mám před sebou stejnost. Jak ale - ptá se Witgenstein - můžu přenést to, co mně jako stejnost ukazuje jedna věc, na dvě, tři a více věcí? ${ }^{2}$ Co bylo pro autora Traktátu těžko řešitelným problémem významu predikátu „být identický“, řešíme snadno: z pozorování (empirického vněmu věci) extrahujeme znaky, které určíme jako „sebeidentitu“ dané věci a z této vlastnosti vytvoříme paradigma identifikace každé další stejnosti. Kromě toho, že se pohybujeme v kruhu (identita je to, co způsobuje stejnost věcí, které jsou identické samy se sebou), jde o typicky exkluzivistický typ myšlení: musíme vyloučit všechno, co do naší představy „nepasuje“, tzn. zbavit se všech přesahů, jinakostí, nestejností, protože bez toho by výsledkem našeho identifikačního jednání bylo poznání neidentity. Ovšem pro určení toho, co je identické samo se sebou, je stanovení diferencí vůči všemu ostatnímu vyjma stejnosti nevyhnutelný předpoklad. Exkluzivismus identity nutí k odlišování

1 Věc je identická sama se sebou. Neexistuje žádný krásnější příklad neužitečné věty, která je nicméně spojena s určitou hrou představy. Je to, jako kdybychom v představě věc vložili do jejího vlastního tvaru a viděli, že do něho „pasuje“. Srv. Wittgenstein, L., Filosofická zkoumání, Praha, Filosofia 2020, § 216.

2 Tamtéž, §§ 215, 218 an. 
a vylučování diferentního. Identita pak vystupuje jako seznam odlišujících atributů, které uvádějí, k čemu osoba patří nevlastním přičiněním (administrativním rozhodnutím), k čemu se sama hlásí (nemusí jít hned o náboženství, spadá sem např estetický vkus) a k čemu se nehlásí (způsoby každé jiné sebeidentifikace).

Obvykle předpokládáme, že osoby se shodným nebo velmi podobným seznamem atributů se shlukují na principu kolektivní identity. Otázka zní, jaké máme argumenty pro tento předpoklad. Např́íklad mohu použít sebeidentifikační znak etnické identity a uvažovat tak, že člověk narozený jako „Ind“ sounáleží s etnicky identickým kolektivem „Indové“. Jaká je ale kolektivní identita Indů žijících v Bengálsku, ve Sjednocených arabských emirátech (kde mohou získat sociální statut „otrok“) a v USA, kde se získáním občanství nabydou také identitu „občan demokratického státu“ s právem volit prezidenta? Je vůbec něco takového jako kolektivní identita? Inventář identifikačních vlastností je tak různorodý, tak individualizovaný, že jsme nuceni bud' na stanovení skupinové (kolektivní) identity rezignovat, nebo z něj vybrat (ovšem podle jakých kritérií?) několik elementárních vlastností (osoba XY je etnický Slovák, umí bruslit a dává přednost prerafaelitům) a vytvářet sebeidentické kolektivy poněkud svévolně a v každém případě ad hoc, anebo se spolehneme na intuitivní „rozumění" (ovšem uznat tvrzení typu „to přece ví každé malé dítě“ jako argument není právě vědecký postup). Počítáme-li s možností sebeidentifikace jako faktickou možností, musíme nutně předpokládat faktické sebevědomí (vědomí sebe sama), které je schopné předložit všechny možné reflektované druhy příslušnosti, sebepřiřazování a přičleňování, stejně jako všechny s tím spojené zájmy a účely, na jejichž základě sebeidentifikace probíhá. Pokud to dokážeme, může potvrdit, že skutečně přináležíme k nejrůznějším společenským identitám: a otevřeme tím problém, jak jsou tyto identity společenské (je identita etnického Slováka, který umí bruslit a je fanouškem hokejového klubu HK Nitra společenská, protože ji sdílí s dalšími fanoušky tohoto klubu?) a nakolik jsou to identity (tvoří zájmová preference bruslícího etnického Slováka identitu?).

Komplexnost problematiky identit brání používat toto slovo v nějakém jednoznačném významu. I ten nejobvyklejší (jde o faktor se zásadní rolí při vytváření interpersonálních a sociálních svazků, počínaje rodinou a konče globální jednotou ohroženého lidstva) se obhajuje těžce, když si povšimneme, že identita se postupně, s tím, jak se vyhrocuje požadavek na jednotlivce, aby byl plně identický, stává základním principem singularizace. Tím se, na rozdíl od individualizace nebo sociální atomizace, neoznačuje rozklad společenských vazeb až po úroveň intimity soukromí, ale souhrn zejména ekonomických procesů s podporou v neoliberální 
politice, jejichž cílem je nahrazení masového konzumerismu individualizovanou výrobou, přizpůsobenou sebeidentifikaci jednotlivých spotřebitelů. $\mathrm{V}$ principu jde o takovou nabídku zakázkové produkce, která by byla s to udržet míru akumulace na úrovni odpovídající ziskům z masové výroby určené pro masovou spotřebu. Během posledních desetiletí jsme mohli sledovat symptomy tohoto přerodu spíš na extravagantních případech, jež nedávaly žádný smysl ekonomicky, ale byly nesmírně cenné pro změnu myšlenky sebeidentifikace od skupinovosti (módnosti, uniformity, stádnosti) k singularizaci: zlaté mobily posázené diamanty, unikátní osobní automobily, perlet’ové vyhřívané WC s ukazatelem aktuální teploty na Marsu, rouška z 18-karátového bílého zlata zdobená 3600 bílých a černých diamantů s filtrem N99 a podobné výstřednosti připravovaly novou střední třídu na myšlenku, že skutečnou identitou disponuje jen ten, kdo se odlišuje. ${ }^{3}$ Identita je již běžnou součástí reklamy, což znamená, že se zahrnuje jako konkrétní náklad do ceny zboží: protože reklama již není nabídkou, ale povelem zákazníkovi, může obsahovat také sociálně velmi dynamický prŕíkaz „bud' svůj“, tedy dej průchod své identitě, která se rovná upravení spotřeby podle principu singularizace.

Přinejmenším v tomto ekonomickém kontextu (který ale zpravidla bývá tím rozhodujícím) se identita a sebeidentita nemyslí jako sjednocující, ale jako singularizační faktor. Proti tomu lze nyní postavit sociologicky ověřené zjištění, že na základě představ o identitě se vytvářejí minimálně dvě formy sociálních seskupení: za prvé čistě nominální seskupení (šachisté, lidé s velikostí bot 43 , diletanti $v$ dějinách německé filosofie...), a za druhé historicky vzniklá společenství (nacionálního charakteru, jazykové pospolitosti, genealogicky spojené skupiny). Zatímco u taxonomických „tříd“ nedosáhneme z hlediska identity žádný posun (identifikace s názorem či míněním „tato jízda tramvají byla skvělá“ je sice možná, protože lze potvrdit „V tom se s tebou ztotožňuji“, ale to ještě nevytváří svébytnou identitu), je u historicky utvořených pospolitostí situace složitější. Především znovu

3 Z hlediska politické ekonomie skutečně platí, že pro udržení stávajících zisků není nutné zvyšovat spotřebu v ekonomicky zaostalých zemích, a proto není ani nutné řešit rozpor mezi globální chudobou a nadbytkem. Dostatečně rozvinutá singularizovaná výroba dle limitované poptávky ve stále automatizovanějších (digitalizovaných) provozech je ekonomicky rentabilnější. Když přistupujeme na ideu, že jsme tím víc sebeidentičtí, čím víc produktů odpovídá naší personalizaci a našim výlučným zakázkám, přistupujeme zároveň na stávající rozvrstvení globálních majetkových poměrů, akceptujeme stav mezi vítězi a poraženými globalizace a pomáháme petrifikaci neoliberálních teorií ekonomie, politiky a společnosti, do kterých spadá také axiom, že práce pro všechny v digitalizované ekonomice prostě nebude, tzn. že člověk nebude mít hodnotu již ani jako pouhý pronajímatel vlastní pracovní síly. 
se potvrzuje, že identita vždy vystupuje jako polysémantický pojem, který můžeme myslet odděleně od individua (historická společenství nemyslíme v př́mé závislosti na jednotlivcích, naopak jsou to tyto skupiny, které propůjčují identitu svým členům; typicky v náboženských skupinách, tajných společnostech, jazykově založených společenstvích, rodokmenem spojených seskupeních). Pro chápání identity proto nepostačuje pouze lexikální výzkum, ale rozhodující je historická sémantika: výrok typu „mám slovenskou identitu“, „moje identita je židovská“ apod. musí být sám schopen sdělit, jaký je jeho význam.

Nejčastější chyba v rozvažování, která vede k pokřivení této myšlenky, spočívá v záměně „významu“ a „hodnoty“: zpravidla se ukazuje na tezi „tato hodnota“, resp. soubor nebo žebříček hodnot mě vede k identifikaci se subjektem, který o sobě tvrdí, že ji vyznává a dokáže ji prosadit jako obecnou normu. Ztotožnění s ideou je abstraktní proces, který obsahuje několik důležitých fenomenologických postupů (zejména reduktivního rázu; očištění ideje v původním stavu a zbavení nepatřičných historických interpretací); tím se idea vyjímá z aktuálních vazeb, získává rysy universálnosti a nadčasovosti a může být prohlášena za následováníhodnou hodnotu. S čím se ale identifikujeme, když se identifikujeme s hodnotami?

První problém předpokládá kladnou odpověd' na otázku, zda hodnoty jsou: je to otázka po jejich ontologickém statutu ${ }^{4}$, který nevznikne tím, že o hodnotách filosofové po staletí disputují (to dělají, i když jde o jiné věci, třeba o sublunární prostor, prvního nehybného hybatele nebo o skutečný a pravý svět pravdivých idejí), ale zřejmě tím, že poukážeme, jak a v čem jsou hodnoty obsahově a významově zakotvené, aby se nemohly měnit s každým dílčím posunem interpretova hlediska. Dokud to neumíme a otázka co hodnoty jsou a jak jsou (pokud jsou) není řešitelná jinak než afirmativně, musíme se smírít s tím, že „hodnota“ je význam, který je věcem a stavům přiřazován na základě našeho domnění, že jsou morální nebo nemorální, dobré nebo špatné, cenné nebo bezcenné, usilováníhodné nebo zavrženíhodné. Jako taková se "hodnota" vymyká analýze; můžeme sledovat, co lidé, dílčí veřejnosti nebo společenství vyznávají, oč usilují, po čem touží a co brání např. tím, že učí své děti témuž vyznání, ale nemůžeme je vědecky analyzovat. Spravedlnost, čest, věrnost, odpovědnost apod. jsou abstraktní ideové konstrukty, které plně a bezezbytku závisejí na kontingentních historických kontextech a jejich náhodnost

4 Zásadně se nejedná o tzv. hodnotový relativismus, který předpokládá, že hodnoty svůj ontologický status mají a pouze uvádí relace, v nichž hodnoty vystupují jako hodnoty; sám fakt, že něco je hodnotou pouze v určitém vztahu, lze zpochybnit pouze důkazem existence absolutních (tj. ničím nevázaných a mimo všechny vztahy stojících) hodnot. Takový důkaz nebyl nikdy podán. 
znemožňuje precizovat, co znamenají a čím jsou (resp. nejsou) mimo své situační vazby. Osoba, která udává svůj hodnotový žebříček jako axiální strukturu své identity, mluví ve skutečnosti o nedefinovatelném souhrnu náhodných stavů a okolností, do něhož se vejde její koncepce či obraz světa, její způsob výkladu dějinné situace, v níž se nachází, a její forma a obsah seberozumění. Co má ale toto veskrze kontingentní určení společného s hodnotami a identitou?

Z hlediska analýz konstituování a praktického vlivu identit na utváření společenského organismu fakticky nic. Identifikujeme se přes hodnoty, a přitom neprovádíme kritickou reflexi identifikační korelace. Identita a sebeidentifikace má určitou působnost na formování vztahů uvnitř společnosti a vně k obklopujícímu prostředí. Je tím účinnější, čím méně je reflektovaná, a pouze se akceptuje a osvojuje jako danost. Čím kritičtější je prostředí identifikace (může být pouze spekulativnější, tj. nadané vyšší schopností imaginace), tím složitější je také idea identity ztotožněná s hodnotou: avšak aby identifikační teze působila, musí být relativně jednoduchá, srozumitelná, na otázky musí dávat bez prodlení důvěryhodnou odpověd; pokud působí opačně a místo odpovědi vyvolává další otázky, připomíná historickou zkušenost jako důvod vlastního sebezpochybnění, volá po srovnání s jinými odpověd'mi a identifikační korelaci spíše komplikuje, musí být z prostředí vymezeného pro individuální identifikaci ihned vyloučena. Stává se totiž skepsí, odbornou pochybností; jenže skepse a identita nejsou př́liš souladné postoje.

Druhý problém vychází ze zjištění (dnes stále běžnějšího), že se identifikujeme s „hodnotami“, které mají formu tzv. vědeckých tvrzení, tzn. jsou podporovány jednou z nejsilnějších dostupných autorit a pokud neznáme adekvátní prostředky nutné pro rekonstrukci jejich argumentace, pak je ani nedokážeme verifikovat. „Popularizace“ čili zlidovnění vědy není nic, co by se ve vědě setkávalo se skutečným nadšením; zkušenosti jsou mnohdy negativní, protože místo popularizace se běžně a bez rozlišování setkáváme se zkreslujícími simplifikacemi. Málokterý vědec se dostane ve svém oboru tak daleko, aby ho mohl přiblížit na jednodušší, podstatně srozumitelnější úrovni, než na jaké probíhá samotný výzkum; nadto mají vědci obvykle dostatek vkusu na to, aby z popularizace neudělali výhodný obchod se senzacemi, jakými jsou v posledních letech líčení všemožných způsobů zániku života na planetě Zemi a dalších armageddonů.

\section{Identita jako kontextuální diferenciace}

Na elementární rovině ř́ká výraz „kontext“, že prvek nějakého celku lze obsahově vymezit jen na pozadí tohoto celku. Švýcarský lingvista Ferdinand 
de Saussure se domníval, že jazyk je systém diferencí, ovšem samy diference nejsou zřejmé zásluhou jazyka, ale kontextu, do nějž jazyk spadá jako jedna z mnoha dalších souvislostí (Saussure 1916). Diferencujeme kontextuálně, a protože na diferenci se zakládá také přisuzování významu, je kontextuální rovněž signifikace. Kontext by tak bylo možné popsat jako další systém diferenciací.

Široký obecný historicko-sociální systém diferenciací je určující pro bazické presupozice jakékoli teorie poznání, včetně té, jejímž předmětem je identita. Bezpředpokladové poznání je iluze a objektivita chápaná jako eliminace subjektivních presupozic je chybně položené měřítko, pro které neexistuje jednotka. Poznání vychází jedině ze subjektu a jeho předpokladového př́stupu k poznávaným objektům; míra ovlivnění poznatků subjektivismem není odvoditelná z odchylek od jakéhokoli ideálu objektivity, ale ze znalosti co nejvyššího počtu kontextuálních faktorů, jimiž jsou presupozice formovány.

Pokud osoba XY tvrdí, že zná svou identitu, pak musí říci, čím je, jaká je, co umí a čeho dosahuje, tzn. musí být schopná jasně určit své sebeidentifikující diference vůči ostatním osobám. Pro sebevymezení, sebeztotožnění a sebezdůvodnění osoby XY není podstatné, v čem je stejná jako jiné osoby (zda sdílí podobné nebo stejné ideje, zda s nimi vytváří specifickou dílčí veřejnost, zda sdílí společný jazyk, zda má stejné hodnotové představy a morální preference, atd.), ale v čem jsou její rozlišující rozdíly, čili to, co způsobuje schopnost rozlišení. Rozdíl se neurčuje prostřednictvím toho, co v komparovaném objektu (např. jiných osobách není, ale naopak stanovením, co je prezentní v osobě XY - jen to vytváŕí její nezastupitelnost, kterou může deklarovat jako svou identitu. Rozpoznání a určení rozlišujících rozdílů osoby dává naději na nesubstancialistickou, antiesencialistickou sebeidentifikaci, která je ovšem vždy agonistická.

Agonický kontext tvoří prostředí pro zpřesnění možností, kdy a jak používat výraz „identita“, avšak nijak ho nezbavuje jeho víceznačnosti.

\subsection{Jak vzniká význam}

Identita, která se utváří v kontextu historických pospolitostí (veřejností), se zpravidla konstituuje dlouhodobě. Proto se do ní promítá vliv mnoha různých faktorů, které se projevují v různých historických souvislostech a ve významu, jenž se pojí právě s těmito souvislostmi. Podstatná ale není otázka, který význam je po delším historickém vývoji dané pospolitosti určující pro interpretaci identity; musí jí předcházet objasnění jiného problému, a to, odkud se takový význam bere, kde, jak a proč vzniká, zda je nějakým způsobem "daný“ a jde jen o to ho v pravou chvíli rozeznat 
a pojmenovat. K výkladu používám jako exemplum výrok typu „mám slovenskou identitu" a otázka zní, jak vzniká jeho význam.

Začít můžeme od nejjednoduššího: v lineární manifestaci textu (zde ve větě „mám slovenskou identitu“) se jeho intence nevyjevuje. Interpret o ní může mluvit tehdy, pokud se rozhodne, že ji v textu uvidí, což zase může pouze, když ji do textu „vloží“. Je to jeho dohad, který předkládá jako rozumění. Zda existuje nějaká na čtenáři nezávislá „objektivní“ a textu samému vlastní intence (např. autorova), není rozhodnutelné jinak než dohadem. To se netýká koherence textu ani představy, že za těchto okolností jsou všechny interpretace stejně platné, protože některé interpretace jsou prokazatelně mylné. Týká se to pouze zjištění, že při interpretaci se zdůrazňují jedny aspekty na úkor druhých v závislosti na tom, o jaké intenci se interpret dohaduje. Aspekty nejsou všechny rovnocenné, některé mohou zasahovat hluboko do textové struktury, jiné se s ní mohou míjet. Znamená to, že nelze rozhodnout, která interpretace je definitivně pravá („nejlepší možná“), ale lze určit, která je mylná: ta, která se neřídí vnitřní koherencí textu jako základním pravidlem interpretace. Koherenci textu ale nevyjádří sám lineární text; potřebujeme k tomu metajazyk, dovolující komparaci daného textu a jeho interpretace. Takový metajazyk si identitní narace nevytvořila a nadále předpokládá, že z důvodu své domnělé specifičnosti vystačí se svým objektovým jazykem (přitom obojí jsou součásti jednoho a téhož jazyka).

Pokud jde o pochopení, můžeme tím myslet pouze správnou sémantickou interpretaci nebo správnou kritickou interpretaci. Sémantická interpretace znamená výchozí, elementární vyplnění lineární manifestace textu nějakým významem, které provádí čtenář při četbě jako běžnou a ničím zvláštní sémiózu. Kritická interpretace je naopak sémiotický akt, kdy se pátrá na metajazykové úrovni po důvodech, které vyvolávají konkrétní způsob zvýznamnění daného textu (signifikaci). Teze o „poznání pravdivého významu“ je vedle toho smysluprázdná: nic jako „pravdivý význam“ neexistuje.

Protože neexistuje pravdivý význam textu, nemůže být signifikace konečná. Snaha o poznání intence daného textu vychází z předpokladu, že v textu existuje vedle toho, co chtěl říci jeho autor, ještě něco, co ř́íká text sám nezávisle na autorovi. Takový předpoklad není vůbec samozřejmý: spolu s ním přijímáme myšlenku, že „text mluví", tzn. že text je schopen něco sdělovat bez ohledu na to, jak ho vygeneroval autor. A tato domněnka v sobě obsahuje další předpoklad, totiž že autor může generovat text bez toho, aby disponoval jeho rozuměním (zde: můžu napsat větu „mám slovenskou identitu" a přitom nemusím umět vysvětlit, co tím myslím; jinak 
řečeno, nerozumím tomu, co tvrdím, ale přesto provádím nějakou signifikaci). Je textový objekt nezávislý na svých interpretacích? Čistě formálně nahlíženo, ano. Formální hledisko ale samo o sobě nic závažného neříká, protože vedle něj je tu vždy ještě kontext, na němž interpretace textu (jakožto formy jeho existence) nepochybně závisejí. Při určování významu identifikačních vět se zpravidla nedoceňuje, že kontext je modus signifikačního jednání; místo toho se připisuje rozhodující slovo intersubjektivnímu ověřování potvrzování významu komunitou sebeidentických osob (zde: pospolitost Slováků intersubjektivně potvrdí, že „být Slovákem“ má identifikační význam, protože... a zde bude stát nějaké hodnotové zdůvodnění), aniž bychom kalkulovali s mírou konjunkturalismu, populismu, nacionalismu a dalších deformačních okolností.

Význam, který se přisuzuje identitě historicky vzniklých pospolitostí, je autorizován na výchozí úrovni stavem daného jazyka $v$ daném historickém kontextu. I když je obojí proměnlivé, neznamená to zpochybnění každého významu a každé interpretace: kontextualita je naopak kritériem rozumnosti interpretace a signifikace. Jakmile se začne s interpretací, jejímž cílem je pochopit a doložit význam, pracuje se nadále již jen se znaky a jejich sémantickými komponentami. Znak není redukovatelný žádnou fenomenalitou: myšlenka, že se za označenými fenomény (zde: „slovenská identita") vyjeví něco pravdivého, podstata, hlubina, pravda, skutečnost jaká je, ukazuje pouze na trvalý problém intuitivního realismu interpretů. To, že popíšeme určitou skutečnost (např. existenci Slováků) jako manifestaci jiné skutečnosti (např. slovenské identity), ještě neznamená, že se tím odhaluje její fakticita: manifestace vytváří znaky, jež nesou význam, který jim dáváme v zájmu naší komunikace. Není zdrojem evidence, vyjma intuitivní.

\subsection{Inkoherence poznání}

Při snaze zjistit, co je tzv. identita, se identita stává hodnotově neutrálním předmětem $\mathrm{v}$ konkrétně aplikované teorii poznání. Teorie poznání je autonomní disciplína, kterou považujeme za zdroj poznatků o kognitivních schopnostech člověka. Úvahy o identitě, jakkoli mohou být emocionálně zabarvené, nezkoumají poznání, ale skutečnosti, kterým přisuzují vztah k tomu, co označuje jako „(sebe-)identifikace“; pro myšlení identity to znamená, že nemá ani nevytváří vlastní prostředky k tomu, aby určila, co je poznatek. Neprovádí dokazování, zda to, co za poznatek považuje, má skutečně hodnotu poznání, nebo zůstává na úrovni domněnky, přesvědčení, víry, názoru. Žádná z disciplín, které se identitou zabývají (psychologie, sociální psychologie, sociologie, filosofie, antropologie, etnografie 
ad.) také nemá možnost verifikovat, kdy a jak se její poznání proměňuje ve vědění - pro takový krok nedisponují žádnou autonomní metodologií.

Tato omezení jsou závažná a přinášejí nemalé problémy. Pojem vědění, který vznikl během vývoje moderní evropské racionality, obsahuje mnoho odlišných výrokových konstrukcí. Ty je nezbytné od sebe odlišovat; „vědět“, „znát“, „poznat“ jsou výrazy, jež mohou ve větách zaujímat různou roli, plnit odlišné funkce, vztahovat se k jiným obsahům a vytvářet různorodé vztahy, z kterých vznikají radikálně odlišné kontexty s kontingentním významem. Zůstanu u svého příkladu: mějme větu „Etnický Slovák zná slovenskou identitu“. Tato věta představuje typ vědění, které se označuje jako propoziční: jedná se o „vědění, že...., kdy se vědění vztahuje na obsah propozice, který je vyjádřen výrokovou formou. Propozice je nositelem pravdivostní hodnoty („pravda“ nebo „nepravda“); pravdivostní hodnotu propozice vytváří ověřitelná skutečnost, tj. něco určitého, co je ve vztahu k předmětu výroku faktem. Pro uvedené disciplíny, tematizující identitu, má propoziční vědění zásadní důležitost a představuje jejich rozhodující kognitivní perspektivu, v které jsou poznatky (zde: poznatky o tom, že etnický Slovák zná slovenskou identitu) formulovány na základě ověření pomocí faktů. Poznání v dotyčných vědách probíhá kumulativně, čili tak, že se shromažd'uje všechno dostupné propoziční vědění o daném předmětu. Nyní se ale klade otázka: vyplývá z nahromaděného propozičního vědění znalost předmětu poznání? Ze znalosti toho, co kdy bylo řečeno a napsáno o znalostech etnického Slováka, ještě neplyne poznání slovenské identity. ${ }^{5}$

Podle hledisek moderních teorií poznání (stejně jako teorií vědy) je identitní narativ neurčitý, hybridní a vysoce nestabilní produkt metodického konstruktivismu, který postrádá jasné vymezení předmětu poznání; zdůvodněné stanovení metod, jejichž poznávací efekt by byl kdykoli verifikovatelný; kriteriálně zakotvené vymezení specifického poznání identity a vědění o komplexním procesu (sebe-)identifikace. Je to způsobeno především systematickým opomíjením argumentace (zejména platnosti kondicionálních argumentů) a zanedbáním povinnosti poskytovat testovatelné argumenty pro existenci faktu označeného termínem „identita“. Otázku, co je platný argument a jak ho odlišit od domněnek, tvrzení, názorů, tezí per analogiam, logicky chybných úsudků a dalších nespolehlivých interpretačních postupů, v diskusích o individuální nebo kolektivní, př́íp. náboženské identitě téměř nenajdeme. Na jejím místě stojí historická vysvětlení, která se koncentrují kolem otázky „jak je možné, že něco..." (např̀.

5 Podobně se ve filosofii zaměňuje schopnost popsat myšlení a tvorbu filosofů (učenců v nejširším smyslu) za filosofické poznání; shromážděním referátů např. o Platónovi nebo o Masarykovi však ještě filosofie, poznání či dokonce vědění nevzniká. 
že něco je „slovenská identita“ nebo „křest’anská identita“) a faktické naplnění této možnosti potvrzují tím, že ji přeformulují jako kauzální vysvětlení („,je nutné, aby...", např. aby právě toto něco bylo „slovenská identita“ nebo „křestáanská identita“).

V oborech jako je sociologie, psychologie, religionistika apod. není takový postup výjimečný, naopak používá se běžně a tyto vědy spíš charakterizuje. Koncept poznání identity se zaměňuje za technologii odkrývání toho, co lze určit jako „identické“ a „neidentické“. Dostupná explananda, tj. identifikované stavy a jevy ve světě, se shromažd'ují na vstupu do systému fabrikace odborného poznání a v něm se zpracují za využití uměle vytvořených komparací, typologií a klasifikací v něco, co bud' je, anebo není „identita“. Explananda se změnila v explanantia, ale v procesu, který je pro teorii poznání vrcholně sporný: je zřejmé, že existují explananda, jako je například skutečnost, že si lidé vyprávějí příběhy, v kterých se líčí minulost, vysvětluje současnost a zmiňují se očekávání od budoucnosti $\mathrm{v}$ celkové souvislosti ztotožnění se s takovým příběhem a jeho strukturou; je zřejmé i to, že tyto příběhy se mohou zahrnovat pod nějaký obecný termín, jako je „pověst“, „báje“, „mýtus“, „legenda“. Vůbec ale není zřejmé, proč by po převyprávění těchto příběhů v identitním narativu (čili v dalším možném příběhu) měl jako vědecký poznatek vzniknout „př́iběh slovenské (české, křest’anské, islámské, šamanské, horalské, mořeplavecké, beduínské, afroamerické atd.) identity“.

Pro užívání odborných termínů musí mít každý obor poznání argumenty, kterými zdůvodní a vysvětlí jejich obsah a význam. Platí zde běžná pravidla vědeckého vysvětlení, která formuluje teorie vědy. Stačí ale využít ta nejzákladnější, abychom zjistili, že např́klad pro explanandum „To je slovenská identita" lze naformulovat v zásadě libovolný počet explanans, aniž by jedno jediné umožňovalo empirickou verifikaci. Žádná z disciplín zkoumajících identitu nepředložila dosud vědecky podložený argument, proč je jedna identita „slovenská“, jiná „ne-slovenská“ a podle jakých ověřitelných kritérií je takové rozlišení vůbec možné. Domnívám se, že zásadní pochybení spočívá v nakládání s různými modalitami tak, jako kdyby byly identické. Z hlediska modální logiky není problém $v$ tom, když se pomocí operátoru $\mathrm{M}$ (možnost) definuje nemožnost jako $\sim \mathrm{M}$ a nutnost jako $\sim \mathrm{M}$; při zkoumáních identity ale nikdy nevznikla axiomatika, která je k tomu nezbytná (Wright 1970, 52-53). Proto se stále zaměňuje fakt, že je možné určit jistou (sociální) zkušenost (at' již formu jednání, chování, reguli, předmět, představu, etické pravidlo, hodnotu atd.) jako součást identifikační korelace, za domněnku, že je to $\mathrm{v}$ daném případě nutné. Tato záměna vede do vědecky neudržitelných situací, v kterých hrají prim kondicionální argumenty (kondicionální věty složené $\mathrm{z}$ antecedentu [jestliže 
p...] a konsekventu [...pak q]). Jakými prostředky lze dokázat, že „,jestliže existují etničtí Slováci, pak existuje slovenská identita“; „jestliže existuje kultura, pak existuje kulturní identita“; jestliže existuje Evropa, pak existuje evropská identita“; „jestliže jsme národ, pak existuje národní identita“? Jsou to věty průkazné zhruba stejně jako tvrzení „jestliže o identitě málo mluvíme, pak máme krizi identity“.

\section{Nebud' sám sebou}

Moderní pojem identity a krize identity vznikl poměrně příznačně pro západní kulturu po 2 . světové válce $\mathrm{v}$ jednom americkém psychiatrickém ústavu, kde se léčili především veteráni. V nemocnici Mount Zion v San Francisco pracovala malá skupina různě zaměřených psychoanalytiků, která se pokoušela přijít na kloub onemocnění, s kterým se lékařská věda dosud nesetkala a neuměla s ním zacházet. Jednalo se o pacienty, kteří prošli krizovými válečnými situacemi, z nichž si odnesli dlouhodobě působící prožitky, a nyní se chtěli jejich vlivu a drastického ovlivňování jejich životů zbavit: chtěli se stát znovu „civilními“, válkou nedotčenými lidmi, jakými byli před válkou. Popsán je konkrétní případ příslušníka námořní pěchoty působící v Pacifiku, před válkou profesí učitele, jemuž se přes snahu lékařů tento „návrat k normalitě“ nedařil. Vedle bolestí hlavy trpěl zejména depresemi, záchvaty paniky a úzkosti, jaké nikdy před válkou nepoznal. Mohl dokonce popsat, kdy se tyto př́znaky projevily: protože odmítal sloužit se zbraní, byl zařazen ke zdravotníkům, kde se při jednom dlouhodobějším nasazení bez vystřídání ocitl stř́ídavě pod japonskými pozemními a leteckými útoky. Při jednom z nich upadl do bezvědomí a probral se z něj s již popsanými přetrvávajícími symptomy. Na rozdíl od 1. světové války už lékaři věděli, že nejde o nervový šok spojený s třesem, ale na základě dlouhodobější terapeutické práce začali tento stav popisovat jako traumatickou destabilizaci vztahů mezi psychickým nitrem pacienta a jeho sociálním prostředím („vnějškem“); ošetřující lékař, psychoanalytik Erik Erikson (1902-1994), formuloval diagnózu jako ztrátu osobní totožnosti v sobě samém a časové kontinuity a pojmenoval ji „krize identity“ - jejím hlavním znakem byla stanovena nejistota (Keller 2017).

Erik Erikson, vlastním jménem Homburger, pocházel z Vídně a do USA se dostal po emigraci roku 1933. Otcem moderní teorie identity, za něhož je považován, se stal tím, že přenesl poznatky z uvedeného př́ípadu na další pacienty, zejména původní americké obyvatele a Afroameričany. U všech konstatoval přícinu v poruchách mezi sociální makro rovinou a osobní mikro rovinou, které se negativně promítly do epigenetického osmistupňového „životního cyklu“ postižených. Tento cyklus je Eriksonův teoretický 
konstrukt, opřený o freudovské náhledy v teorii pudů, avšak přenesené z dětství do dospělosti. Eriksonova kniha (Erikson 1950) byla v Americe považována za levičáckou (zřejmě nepodávala plně americký obraz armády) a proto i zdrženlivě přijímána, takže trvalo až do přelomu 50./60. let, než začala skutečná konjunktura dnešního konceptu identity.

Můžeme jistě brát velmi vážně, jak se množí a prohlubují poruchy mezi individuální mikro- a sociální makro rovinou: nerovnost, prekariát, stres, bída, nemoci, odcizení, trvalá diskriminace, majetkové a sociální rozdíly, genderové rozdíly zpravidla $v$ neprospěch žen, lhostejnost, demokraticky liberální nezájem o jednotlivce, vzdělanostní propadliště, zneuznání jiných na principu výlučnosti rasy, náboženství nebo politické ideologie, tendenčně narůstající resentiment, který ústí v počínající interkulturní paranoie, úpadek schopnosti empatie a schopnosti myšlení vůbec, život ve světě vytvářeném mediálním nátlakem, který se $\mathrm{v}$ př́ípadě odporu okamžitě mění v mediální lynč a exkomunikaci, strach a nejistoty spojené s velmi rizikovým environmentálním vývojem - to a mnoho dalšího nezůstává bez odezvy v nevyrovnanosti myšlení a cítění lidí. Psychické krize jsou jeden z nejrozšířenějších jevů dneška, který doprovází rovněž historicky nebývalá spotřeba psychofarmak; aby člověk mohl fungovat uprostřed tlaků, které jsou na něj vyvíjeny a které na sebe vyvíjí sám, pomáhá si jedy, bud' na lékařský předpis, nebo ( $v$ tom horším př́ípadě) mezi dealery kokainu. ${ }^{6}$

Tato situace je obecně známá, byt' se nijak nepopularizuje. Co ale zůstává úplně zastřeno před celospolečenskou reflexí, je válka identit, která této situaci vládne a pomalu přerůstá v hybridní moderní formu občanské války: identičtí proti neidentickým, bílí proti barevným, adaptovaní proti neadaptovaným, domácí proti cizincům, všichni proti muslimům, homosexuálové proti heterosexuálům, transsexuálové proti homosexuálům, barevní proti bílým, muslimové proti Židům, ženy proti mužům... Teror identity, jemuž jsme kolektivně vystaveni, není bezúčelný; za pokynem „bud' sám sebou" se skrývá několik dalších vysoce specifikovaných příkazů, podle nichž má člověk vést svůj život a řídit vztahy k ostatním životům, pokud chce stát na výsluní sebe sama vědomého, jedinečného a společensky oceňovaného individua s vlastní identitou. Mezi nimi najdeme návod, jak si vybojovat svůj vlastní životní prostor, jak si ho chránit proti ostatním, jaké chování volit pro prosazení svých zájmů, s kým se stýkat a do jakých „bublin“ na sociálních sítích se neřadit, s kým jednat z očí do očí a koho ignorovat, jak se stát součástí funkčních elit a jak v tom zabránit jiným, jak

6 Paradoxně je situace psychicky nemocných, ale zaléčených lidí společensky horší než situace konzumentů drog, mezi kterými se např kokain stává téměř podobně společensky tolerovanou drogou jako je alkohol. 
profitovat ze všech okolností, které se naskytnou (myslet pozitivně a využít každé př́iležitosti má k sobě hodně blízko), kdy být submisivní užitečný idiot a kdy využít ostatní kolem sebe jen pro své účely: jinak řečeno, jsou zde všechny pokyny k tomu jak „být sám sebou“. Požadavek na identitu převádí pozornost od zásadních hlubokých a s neuvěřitelnou tvrdostí využívaných nerovností na dílčí diference, jež se mnohdy týkají zlomku procenta z počtu obyvatel, ale spolehlivě je překrývají a ponechávají k užitku privilegovaných. Zbytek bojuje za to, aby byl sám sebou: aby se jeho osobitost úplně rozplynula v obrazu sebe sama, který si tvoří z vnějšího popudu a podle vnějších předloh.

\section{Závěr}

Snad máme šanci, přestaneme-li se chovat infantilně. Brutalita poměrů v současných společnostech, sílící hrubost, agresivita, spoléhání se na sílu a moc, která již dnes dokáže bez potíží zaručit, že si nejsme rovni ani před zákonem, volání po zákonném právu chodit ozbrojen a moci „bránit své zájmy“ s použitím střelné zbraně, to vše jsou příznaky naší neutuchající dětinskosti, s kterou jsme přijali požadavek identity reformulovaný jako právo na neomezenou svobodu. Lidé vykonávající své funkce ve státní správě, ve vzdělávání, ve vědě, politice nebo podnikání jsou lidé, kteří tvoří velkou společenskou třídu pověřených: nejsou vyvolení, pomazaní ani povolaní, jsou prostě pověření společenskými strukturami a institucionálními systémy. Naší faktickou identitou je „být pověřený“ v situaci historické kontingence: exkluze, diskriminace, křivda a bolest jsou jen naše vlastní reakční pozérství, s kterým se stavíme vưči svému životu. Znamená snad „být identický sám se sebou“, že můj život nebude zraňující, nebude přinášet nespravedlnost, nepohodlí, vykořistování a poškozování, že se z něj ztratí všechno zničující a deptající? Někdo nám slíbil život jako koncert na přání? Na strunu identity brnká ve skutečnosti jen naše nedospělá přecitlivělost: nechtějme být sami sebou, chtějme být dost dospělí na to, abychom se srovnali se svým životem a možná i pomohli dalším, aby se srovnali se svým.

\section{Literatúra}

ERIKSON, E. H. (1950): Childhood and Society. New York: W. W. Norton \& Company. HORYNA, B. (2019): Quod fuimus, estis; quod sumus, vos eritis. Dialektika identity, alterity, uznání a mezí principu. In: Philosophica Critica, 5 (2), 2019, 30-45.

KELLER, E. (2017): Identität - das Andere der Anderen. Web. 13.12. $2020<\mathrm{http}: / /$ geschichtedergegenwart.ch/identitaet-das-andere-der-anderen/>.

SAUSSURE, F. de (1916): Cours de linguistique générale (eds. Charles Bally \& Alert Sechehaye). Lausanne - Paris: Payot. 
WITTGENSTEIN, L. (2020): Filosofická zkoumání. Praha: Filosofia.

WRIGHT, H. G. Von (1970): Explanation and Understanding. New York: Cornell University Press.

Štúdia vznikla s podporou grantu VEGA č. 1/0291/18 Historicko-filozofická analýza environmentálneho myslenia, skúmanie jeho vplyvov na etické, právne a politické myslenie a jeho spoločenská odozva.

\section{Prof. PhDr. Břetislav Horyna, PhD.}

Katedra filozofie FF UKF Nitra

Hodžova 1

94974 Nitra

bhoryna@ukf.sk

orcid.org/0000-0002-6610-246X 